DOI https://doi.org/10.15589/znp2019.1(475).8 УДК 621.45 .034

\title{
INVESTIGATIONS OF LIQUID FUEL SPRAYING VELOCITY INFLUENCE ON CHARACTERISTICS OF A DUAL-FUEL GAS TURBINE COMBUSTOR
}

\section{ДОСЛІДЖЕННЯ ВПЛИВУ ШВИДКОСТІ РОЗПИЛЮВАННЯ РІДКОГО ПАЛИВА НА ХАРАКТЕРИСТИКИ ДВОПАЛИВНОЇ ГАЗОТУРБІННОЇ КАМЕРИ ЗГОРЯННЯ}

\author{
Serhii I. Serbin \\ serhiy.serbin@nuos.edu.ua \\ ORCID: 0000-0002-3423-2681 \\ Badri T. Disamidze \\ badri.diasamidze@nuos.edu.ua \\ ORCID: 0000-0002-1627-9494
}

C. І. Сербін,

докт. техн. наук, професор

\section{Б. Т. Діасамідзе,}

аспірант

\section{Admiral Makarov National University of Shipbuilding, Mykolaiv \\ Національний університет кораблебудування імені адмірала Макарова, м. Миколаїв}

\begin{abstract}
Purpose. This study is dedicated to specifying fluid dynamic characteristics and reducing $\mathrm{NO}_{x}$ emission. Two-phased combustion of dual-fuel gas turbine engines researches are important due to present needs and future environmental safety. Also combining liquid and gaseous state combustion could lead to economic and social benefits. This study is dedicated to specifying fluid dynamic characteristics and reducing $\mathrm{NO}_{\mathrm{x}}$ emission.

Method. Three-dimensional mathematical modeling has been used as a method of research. The analysis of the influence of velocity on $\mathrm{NO}_{\mathrm{x}}$ emission with using working hypothesis of creating a low-emission dual-fuel combustor for a gas turbine engine has been made. An effective method of organizing the working process in a dual-fuel gas turbine combustor is has been used. A low-emission gas turbine combustor with pre-mixing of fuel and air was selected as a research object.

Results. To increase the efficiency of processes in a dual-fuel gas turbine combustor, it is proposed to use the idea of preliminary mixing of liquid fuel with air in axial-radial swirlers. The choice of a mathematical model of liquid fuel burning in a dual-fuel low-emission combustor taking into consideration formation of the main toxic components has been made. Eddy dissipation concept, radiation heat transferring model, specific $(k-\varepsilon)$ turbulence model, discrete phase model have been used for liquid fuel combustion process modeling. Theoretical investigations of nitrogen oxides formation have been carried out for various methods of liquid fuel injection into the channels of axial-radial swirlers of low-emission combustor. Using three-dimensional mathematical modeling, a graph of the nitrogen oxides $\left(\mathrm{NO}_{x}\right)$ dependence on the flow rate of the liquid fuel into the channels of the axial-radial swirlers of the low-emission gas turbine combustor was obtained, taking into consideration the radial mode of fuel supply. The graph of the unevenness of the temperature field was also obtained. The results of three-dimensional mathematical modeling showed the prospect of a radial method of liquid fuel injection into the channels of axial-radial swirlers of a gas turbine lowemission combustor in comparison with the traditional method of liquid fuel supply using centrifugal nozzles. The results of mathematical modeling revealed that fuel supply velocity above $40 \mathrm{~m} / \mathrm{s}$ is prohibited, and the best emission results are at the lowest velocity indicators.

Scientific novelty. As result the knowledge about combustion process in dual-fuel combustion chambers was deepened. Practical importance. This work has been theoretical in nature; however, the obtained results could be used in the State Research and Development Production Gas Turbine Complex “Zorya"-"Mashproekt" when upgrading existing engines.
\end{abstract}

Key words: gas turbine engine; dual-fuel low-emission combustor; combustion process.

Анотація. Мета. Метою роботи є дослідження впливу швидкості впорскування рідкого палива в канали аксіально-радіальних завихрювачів низькоемісійної камери згоряння газотурбінного двигуна (ГТД) потужністю 25 МВт на температурне поле на виході з камери та емісію оксидів азоту.

Методика. Для підвищення ефективності процесів у двопаливній газотурбінній камері пропонується використовувати ідеї попереднього перемішування рідкого і газоподібного палива 3 повітрям в аксіально-радіальних завихрювачах, дрібнодисперсного розпилювання рідкого палива високошвидкісним повітряним потоком після компресора високого тиску, що забезпечить перехід з одного виду палива на інший без зупинки газотурбінного 


\section{ЕНЕРГЕТИЧНЕ МАШИНОБУДУВАННЯ №1 2019}

двигуна та мінімальні викиди токсичних компонентів на основних режимах роботи. Розрахунки проводяться за допомогою тривимірного математичного моделювання.

Результати. Запропоновано ефективний спосіб організації робочого процесу в двопаливній газотурбінній низькоемісійній камері згоряння. Проведено теоретичні дослідження утворення оксидів азоту для різних швидкостей впорскування рідкого палива в канали аксіально-радіальних завихрювачів низькоемісійної камери згоряння. Здійснено вибір математичної моделі вигоряння рідкого палива в двопаливній низькоемісійній камері згоряння з урахуванням утворення основних токсичних компонентів. Тривимірна математична модель вигоряння рідкого палива в двопаливній низькоемісійній камері згоряння ГТД містить у собі такі рівняння: нерозривності, збереження кількості руху та енергії, переносу компонентів кінетичної схеми з урахуванням дисипації вихорів, утворення і розкладання оксидів азоту, переносу характеристик турбулентності, променистого теплообміну у взаємодії з рівняннями моделі дискретної фази. Математична модель емісії оксидів азоту являє собою систему рівнянь масового переносу, які враховують конвекцію, дифузію, а також утворення і розкладання $\mathrm{NO}_{\mathrm{x}}$ та споріднених сполук. За допомогою тривимірного математичного моделювання отримано графік залежності оксидів азоту $\left(\mathrm{NO}_{\text {x }}\right.$ ) від швидкості подачі рідкого палива в канали аксіально-радіальних завихрювачів низькоемісійної камери згоряння ГТД при радіальному способі подачі палива, а також побудовано графік залежності нерівномірності температурного поля на виході з камери згоряння.

Наукова новизна. Отримано нові знання щодо організації робочого процесу в двопаливних камерах згоряння ГТД та нерівномірності температурного поля на виході.

Практична значимість. Дана робота має теоретичний характер, проте отримані результати можуть бути використані в ДП «Науково-виробничий комплекс газотурбобудування «Зоря»-«Машпроєкт» при модернізації існуючих двигунів.

Ключові слова: газотурбінний двигун; двопаливна низькоемісійна камера згоряння; процес горіння.

\section{ПОСТАНОВКА ЗАДАЧІ}

Сучасний світ кидає інженерам та науковцям низку суперечливих викликів. Наприклад, таких: а) знаходження шляхів ефективного використання палива та підвищення ККД газотурбінних двигунів (далі ГТД) за необхідності дотримання вимог екологічних норм щодо промислових викидів [1], однак підвищення цих характеристик часто пов'язане з підвищенням температури перед турбіною $T_{3}$, що своєю чергою може призвести до збільшення утворення термічних оксидів азоту $\mathrm{NO}_{x}[2]$; б) з одного боку, підвищення швидкості та якості розробки двигуна, а з іншого зменшення вартості продукції.

Натурні дослідження процесів розпилювання та горіння палив достатньо проблематичні у зв'язку з високою вартістю матеріальних та людських ресурсів, високими температурами в камері згоряння, але за допомогою сучасних методів математичного моделювання й обчислювальної гідродинаміки такі завдання можуть розв'язуватися 3 високою швидкістю і точністю. Дослідження шляхів удосконалення емісійних характеристик паливоспалюючих пристроїв, що забезпечують вирішення проблеми створення мобільних і високоефективних ГТД наземного та морського призначення, які відповідають вимогам до енергетичних модулів нового покоління і працюють на рідкому й газоподібному органічних паливах одночасно, є актуальною проблемою, розв'язання якої матиме як соціальний, так і економічний ефект.

\section{АНАЛІЗ ОСТАННІХ ДОСЛІДЖЕНЬ І ПУБЛІКАЦІЙ}

Проблему покращення емісійних показників паливоспалюючих пристроїв ГТД висвітлено в кон- венції [1], їі розглядали такі науковці, як Р.C. Melte, D.T. Pratt [2], O. Lindman, M. Andersson, M. Persson, E. Munktell [3], C.I. Сербін [4-6], G.M. Faeth [7], B.F. Magnussen [8], S.B. Pope [9], M. Welch, B.M. Igoe, D. Vilson [10], Е. Синкевич [11], J. Brown [12], Н.J. Kurji [13], I.A. Ibrahim, M.M. Shabaan, M.A. Shehata, T.M. Farag [14], M. Hertel [15]. Цю проблему висвітлено також у технічних виданнях $[16 ; 17]$. Попри велику кількість наукових досліджень у сфері низькоемісійних камер згоряння, методологічні й технічні аспекти вирішення проблеми створення двопаливних камер згоряння розроблені недостатньо. Багато дослідників зосередилося на розв'язанні проблем двопаливних камер згоряння виключно експериментальними методами, і лише деякі зарубіжні вчені, які представляють різні наукові школи та країни (Н.J. Kurji [13], M. Hertel [15]), прагнуть для цього використовувати сучасні методи обчислювальної гідродинаміки.

\section{ВІДОКРЕМЛЕННЯ НЕ ВИРІШЕНИХ РАНІШЕ ЧАСТИН ЗАГАЛЬНОӤ ПРОБЛЕМИ}

Дослідження впливу швидкості розпилювання рідкого палива на характеристики двопаливної газотурбінної камери є одним з етапів теоретичного дослідження фізико-хімічних закономірностей процесів двофазного горіння у двопаливних камерах згоряння за допомогою методів обчислювальної гідродинаміки, що $є$ частиною загальної проблеми створення мобільних, високоефективних та конкурентоспроможних вітчизняних ГТД наземного й морського призначення, які будуть відповідати вимогам до енергетичних модулів нового покоління та зможуть працювати на рідкому і газоподібному органічних паливах одночасно. 
Зазначимо, що комплексні дослідження у цьому напрямі в Україні практично відсутні.

Метою роботи $є$ дослідження впливу швидкості впорскування рідкого палива в канали аксіально-радіальних завихрювачів низькоемісійної камери згоряння газотурбінного двигуна потужністю 25 МВт на температурне поле на виході $з$ камери та емісію оксидів азоту.

\section{МЕТОДИ, ОБ'СКТ ТА ПРЕДМЕТ ДОСЛІДЖЕННЯ}

Як метод дослідження обране тривимірне числове моделювання 3 використанням моделей турбулентності, кінетичних механізмів окиснення вуглеводнів та утворення токсичних компонентів у хімічно реагуючих потоках.

Об'єктом дослідження є процеси в низькоемісійній камері згоряння з попереднім перемішуванням паливно-повітряної суміші ГТД потужністю 25 МВт виробництва «Зоря»-«Машроєкт» [6].

Предмет дослідження - фізико-хімічні закономірності процесів горіння рідкого палива у двопаливній газотурбінній камері згоряння ГТД.

\section{ОСНОВНИЙ МАТЕРІАЛ}

Як об'єкт дослідження обрано низькоемісійну камеру згоряння з попереднім перемішуванням паливно-повітряної суміші газотурбінного двигуна потужністю 25 МВт виробництва «Зоря»-«Машроєкт» [6].

Основним елементом такої камери є пальниковий пристрій, що складається 3 двох радіальних завихрювачів першого і другого каналів, за якими розташовані кільцеві камери змішування. Частинка повітря, що надходить через завихрювач першого каналу, становить близько 12\% від сумарної витрати повітря через жарову трубу, а через завихрювач другого каналу - близько 61\%. Паливний газ подається через ряд отворів, виконаних в лопатках радіальних завихрювачів першого і другого каналів.

У даній роботі наводяться результати числового моделювання процесів розпилювання та згоряння дизельного палива в низькоемісійній камері згоряння. Була проведена серія розрахунків з метою визначення впливу швидкості впорскування рідкого палива при його радіальній подачі в канали аксіально-радіальних завихрювачів на характеристики камери згоряння. При проведенні розрахунків ураховано, що 95\% палива подається в радіальному напрямку через зовнішній завихрювач фронтового пристрою, а 5\% палива подається також у радіальному напрямку через внутрішній завихрювач. Цей спосіб подачі палива був обраний з огляду на попередні дослідження, а також результати експериментально-теоретичних досліджень компанії “Siemens”, які були проведені для камери згоряння SGT-750 [3]. Базові параметри розпилювання дизельного палива такі: швидкість витікання крапель - 50 м/с, середній діаметр крапель у спектрі розпилювання - 50 мкм, кут розпилювання палива $-35^{\circ}$.

Для розрахунків горіння рідкого палива в низькоемісійній камері згоряння обрано модель дискретної фази DPM (Discrete Phase Model), яка розраховує траєкторії руху окремих частинок [4].

Для використання детальних хімічних механізмів горіння в турбулентних потоках з флуктуаціями зроблене таке припущення: реакції відбуваються в малих турбулентних структурах, які називаються дрібномасштабними реакторами [7], що являють собою реактори постійного тиску, початкові умови для яких визначаються концентрацією компонентів і температурою в осередках. Швидкості реакцій визначаються за виразом Арреніуса та інтегруються числовим методом за допомогою ISAT-алгоритму [8]. Подібні припущення зроблені в рамках так званої концепції дисипації вихорів - Eddy-Dissipation-Concept (EDC), яка і була застосована в даному дослідженні.

Модель інертного нагріву використовується, коли температура краплі менша за температуру випаровування. Для розрахунку зміни температури частинок за часом $T_{p}(t)$ застосовується рівняння теплового балансу, що враховує конвекційний та радіаційний переноси теплоти:

$$
m_{p} c_{p} \frac{d T_{p}}{d t}=h A_{p}\left(T_{\infty}-T_{p}\right)+\mu_{p} A_{p} \sigma\left(\theta_{R}^{4}-T_{p}^{4}\right),
$$

де $m_{p}$ - маса частинки; $c_{p}-$ питома теплоємність частинки при постійному тиску; $A_{p}-$ площа поверхні частинки; $T_{\infty}$ - локальна температура газової фази; $h$ - коефіцієнт тепловіддачі; $\varepsilon_{p}$ - коефіцієнт випромінювання частинки; $\sigma$ - стала Стефана-Больцмана; $\theta_{R}$ - радіаційна температура.

Коефіцієнт тепловіддачі $h$ обчислюється 3 використанням кореляції Ранца і Маршала (Ranz, Marshall):

$$
\mathrm{Nu}=\frac{h d_{p}}{k_{\infty}}=2,0+0,6 \operatorname{Re}_{d}^{1 / 2} \operatorname{Pr}^{1 / 3},
$$

де $k_{\infty}-$ коефіцієнт теплопровідності газової фази; $\mathrm{Re}_{d}$ - число Рейнольдса, яке визначається діаметром краплі та їі відносною швидкістю; $\mathrm{Pr}$ - число Прандтля для газоподібної фази.

Радіаційна температура і падаюче випромінювання вираховуються так:

$$
\theta_{R}=(G / 4 \sigma)^{1 / 4} ; G=\int_{\Omega=4 \Pi} I d \Omega,
$$

де $I$ - інтенсивність випромінювання; $\Omega$ - тілесний кут.

Наведені вище рівняння інтегруються в часі із застосуванням наближеної лінійної форми, яка передбачає, що температура частинок змінюється досить повільно.

Модель випаровування ініціюється, коли температура частинки досягає температури випаровування 


\section{ЕНЕРГЕТИЧНЕ МАШИНОБУДУВАННЯ №1"2019}

$T_{\text {vap }}$, і використовується доти, доки температура не перевищує значення точки кипіння $T_{b p}$ або доки летючі компоненти частинок повністю не будуть витрачені (в разі горіння залишкових палив).

Рівняння теплообміну частинок 3 газовою фазою при їх випаровуванні враховує конвективний і радіаційний потоки теплоти, а також процес пароутворення:

$m_{p} c_{p} \frac{d T_{p}}{d t}=h A_{p}\left(T_{\infty}-T_{p}\right)+\mu_{p} A_{p} \tilde{\mathrm{A}}\left({ }_{R}^{4}-T_{p}^{4}\right)+\frac{d m_{p}}{d t} h_{f g}$,

де $h_{f g}$ - прихована теплота випаровування.

Маса частинки протягом випаровування зменшується відповідно до балансового рівняння:

$$
m_{p}(t+\Delta t)=m_{p}(t)-N_{i} A_{p} M_{w, i} \Delta t
$$

де $M_{w, i}$ - молекулярна вага частинки $i$.

Ступінь випаровування визначається дифузійним потоком парів палива в газовій фазі, пропорційним градієнту концентрацій парів на поверхні частинки і в газовому середовищі:

$$
N_{i}=k_{c}\left(C_{i, S}-C_{i, \infty}\right)
$$

де $N_{i}$ - молярний потік випаруваної речовини; $k_{c}$ - коефіцієнт масообміну; $C_{i, S}-$ концентрація пари на поверхні краплі; $C_{i, \infty}-$ концентрація пари в газовому середовищі.

Коли температура частинки досягає температури кипіння, то використовується таке рівняння для швидкості зміни іiі діаметра: $-\frac{d\left(d_{p}\right)}{d t}=\frac{2}{\rho_{p} h_{f g}}\left[\frac{2 k_{\infty}\left[1+0,23 \sqrt{\operatorname{Re}_{d}}\right]}{d_{p}}\left(T_{\infty}-T_{p}\right)+\mu_{p} \sigma\left(\theta_{R}^{4}-T_{p}^{4}\right)\right]$.

Для спрощення передбачається, що при кипінні температура краплі не змінюється. Енергія, необхідна для випаровування, враховується у вигляді джерельного члена в рівнянні збереження енергії газової фази. Випаровування рідини також є джерелом хімічного компонента $i$ для газової фази. У дослідженні застосовується спосіб впорскування палива single: моделюється потік, що проходить через ряд одиничних труб малого діаметра, що підведені в канал завихрювача.

На рис. 1-4 зображені розподіли таких основних параметрів у повздовжніх перерізах жарової труби: температур, швидкостей, кінетичної енергії турбулентності й концентрацій оксидів азоту за двох значень (мінімального та максимального) швидкості витікання рідкого палива в канали аксіально-радіальних завихрювачів (5 і $50 \mathrm{~m} / \mathrm{c})$.

Існує тісний взаємозв'язок між розподілом температур, об'ємними викидами азоту, швидкостями, характером потоку і турбулентністю. При збільшенні швидкості радіальної подачі палива збільшується емісія оксидів азоту за рахунок збільшення сумарної протяжності факела палива (див. рис. 1 і 4). Характер і розміри зони зворотних течій усередині жарової труби також дещо змінюються (див. рис. 2) за рахунок невеликого підвищення інтенсивності турбулентності (див. рис. 3) при збільшенні різниці в швидкостях рідкої та газоподібної фаз.
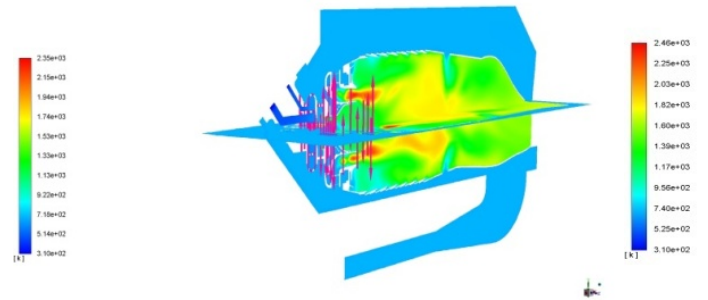

a)

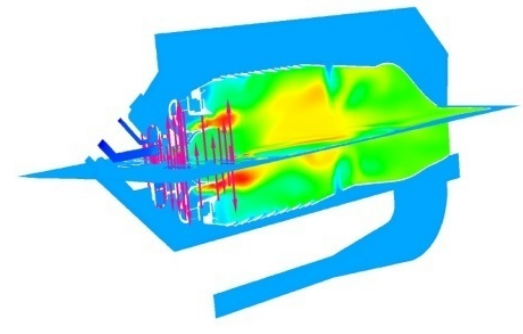

б)

Рис. 1. Розподіл температур газу (К) уздовж жарової труби камери згоряння за швидкостей впорскування: a) $5 \mathrm{M} / \mathrm{c}$; б) $50 \mathrm{M} / \mathrm{c}$
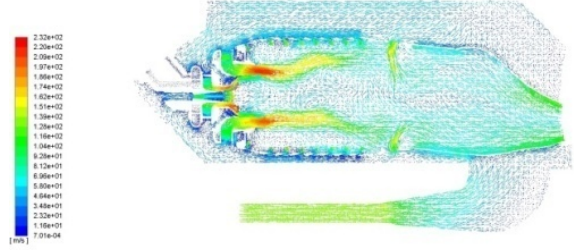

a)

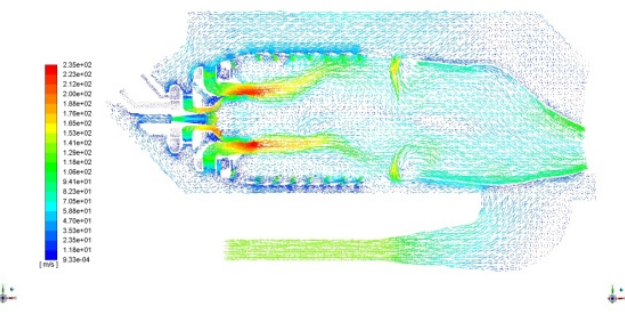

б)

Рис. 2. Розподіл швидкостей (м/с) та аеродинамічна структура потоку в жаровій трубі за швидкостей впорскування: a) $5 \mathrm{~m} / \mathrm{c}$; б) $50 \mathrm{~m} / \mathrm{c}$ 
Зазначимо, що у разі радіальної подачі рідкого палива процес випаровування крапель та перемішування парів 3 повітрям відбувається достатньо швидко. Процес горіння розпочинається навіть у каналах завихрювачів, що може призвести до підвищення температури металевих поверхонь, нагароутворень і зниження надійності жарової труби в цілому. Для вирішення цієї проблеми в наступних дослідженнях планується виконати перерозподіл кількості повітря, що надходить в канали завихрювачів і змішувач.

Залежність викидів оксиду азоту від швидкості подачі рідкого палива подана на рис. 5. Очевидно, що зменшення швидкості витікання палива в канали завихрювачів сприяє зниженню емісії оксиду азоту, що вимагає конструювання більш ефективних паливорозпилювальних пристроїв.

На рис. 6 наведені діаграми середньої нерівномірності температурного поля $\delta$ у вихідному перерізі жарової труби.

Коефіцієнт загальної нерівномірності поля температур визначався за такою формулою:

$$
\delta=\frac{T_{\max }-T_{\min }}{T_{a v}},
$$

де $T_{\max }, T_{\min }, T_{\alpha}$ - максимальна, мінімальна й осереднена температури газів у вихідному перерізі.
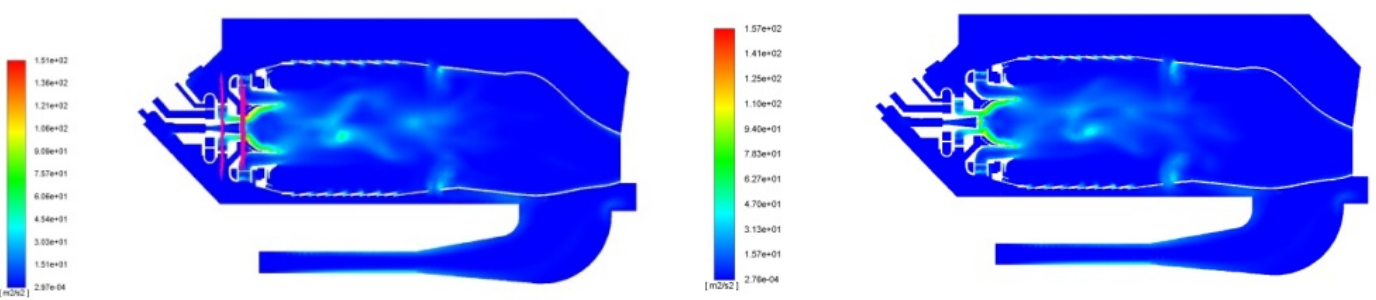

a)

i:

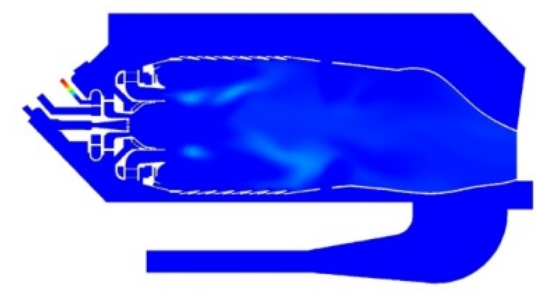

a)

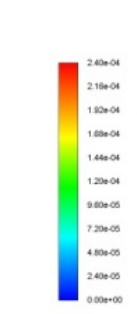

i.

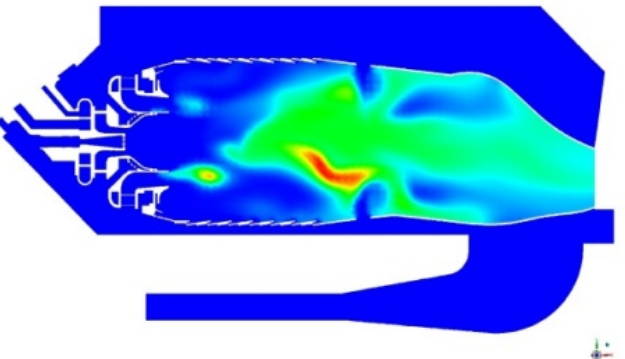

б)

Рис. 3. Розподіл кінетичної турбулентності $\left(\mathrm{M}^{2} / \mathrm{c}^{2}\right)$ у жаровій трубі за швидкостей впорскування: a) 5 м/с; б) 50 м/с

Рис. 4. Розподіл об'ємних концентрацій оксидів азоту в жаровій трубі за швидкостей впорскування: a) 5 м/с; б) $50 \mathrm{M} / \mathrm{c}$

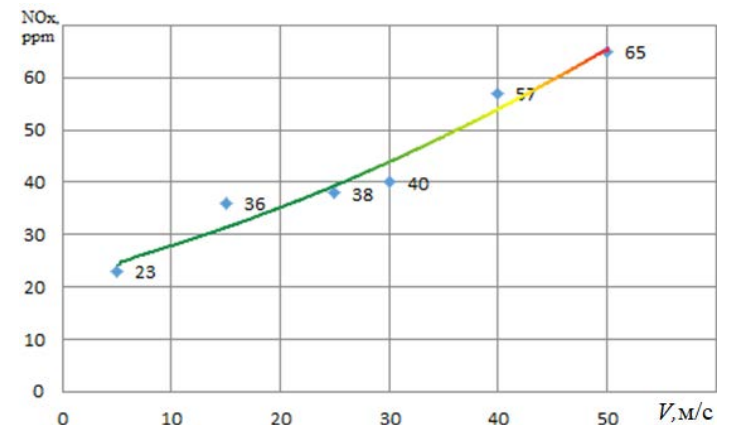

Рис. 5. Вплив швидкості подачі палива в камеру згоряння на викиди оксидів азоту у вихідному перерізі жарової труби

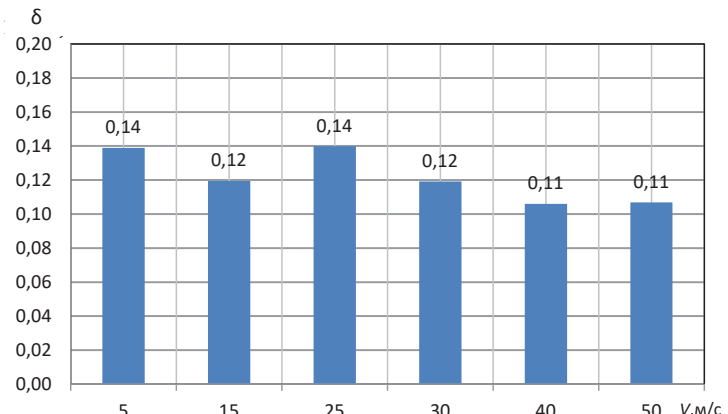

Рис. 6. Нерівномірність температурного поля за різних швидкостей подачі палива в камеру згоряння 


\section{ЕНЕРГЕТИЧНЕ МАШИНОБУДУВАННЯ №1 2019}

Дані рис. 6 відображують незначний вплив швидкості подачі рідкого палива в канали завихрювачів на нерівномірність температурного поля на виході камери. Це зумовлено достатньо малим часом вирівнювання швидкостей рідкої та газоподібної фаз в об'ємі жарової труби.

\section{ОБГОВОРЕННЯ ОТРИМАНИХ РЕЗУЛЬТАТІВ}

Отримані результати тривимірного математичного моделювання підтвердили доцільність вибору радіального способу підведення рідкого палива в канали завихрювачів низькоемісійної камери згоряння ГТД порівняно з традиційним відцентровим способом подачі палива та виявили закономірності вибору діапазону раціональних значень швидкостей впорскування рідкого палива при його радіальній подачі.

\section{ВИСНОВКИ}

Досліджено вплив швидкості радіальної подачі палива в канали аксіально-радіальних завихрювачів двопаливної камери згоряння газотурбінного двигуна потужністю 25 МВт на викиди оксидів азоту та нерівномірність температурного поля у вихідному перерізі жарової труби.

Збільшення швидкості радіальної подачі рідкого палива в канали внутрішнього і зовнішнього завихрювачів жарової труби із 5 до $50 \mathrm{M} / \mathrm{c}$ призводить до зростання розрахункової емісії оксидів азоту із 24 до 66 ррт та суттєво не впливає на сумарну нерівномірність поля температур у вихідному перерізі $(14 . .11 \%)$.

\section{REFERENCES}

[1] Yevropeyskiy Soyuz: Sovet Yevropeyskogo Soyuza (2010). Direktiva 2010/75/YES Yevropeyskogo parlamenta i konsiliuma ot 24 noyabrya 2010 goda o promyshlennykh vybrosakh (integrirovannoye predotvrashcheniye $i$ kontrol' zagryazneniya) [European Union: Council of the European Union (2010). Directive 2010/75 / EC of the European Parliament and of the Council of 24 November 2010 on industrial emissions (integrated pollution prevention and control)]. Prilozheniye V «Tekhnicheskiye polozheniya, svyazannyye so szhigayushchimi ustanovkami» [Appendix V «Technical Provisions Related to Combustion Plants»], Part 1, paragraphs 6, 59-61.

[2] Melte, P. C., \& Pratt, D. T. (1974). Measurement of Atomic Oxygen and Nitrogen Oxides in Jet Stirred Combustion Proc. 15th Symposium (International) on Combustion. - The Combustion Institute, USA, 1061-1070.

[3] Lindman, O., Andersson, M., Persson, M., \& Munktell, E. (2014). Development of a liquid fuel combustion system for SGT750: Proceedings of ASME Turbo Expo 2014: Turbine Technical Conference and Exposition GT2014, June 16-20, 2014. Germany: Düsseldorf.

[4] Serbin, S. I., \& Vilkul, S. V. (2009). Research the influence of liquid fuel atomization parameters on the temperature field and the ecological characteristics of the combustion chamber. Vestnik dvigatelestroyeniya, 3, 93-97.

[5] Burunsuz, K. S., Kuklinovsky, V. V., \& Serbin, S. I. (2019). Investigations of the emission characteristics of a gas turbine combustor with water steam injection. Refrigeration Engineering and Technology, 55 (2), 77-83.

[6] Serbin, S., \& Mostipanenko, H. (2006). Chyslove modelyuvannya protsesiv horinnya v eksperymentalnomuvidsiku hibrydnoyi kamery zhoryannya HTD potuzhnistyu $25 \mathrm{MWt}$ [Numerical simulation of combustion processes in the experimental compartment of a 25 MW MW hybrid combustion chamber]. Visnyk Natsionalnoho tekhnichnoho universytetu «Kharkivskyy politekhnichnyy instytut». Zbirnyk naukovykh prats. Tematychnyy vypusk: "Enerhetychni ta teplotekhnichniprotsesy y ustatkuvannya», 5, 59-67 (in Ukrainian).

[7] Faeth, G. M. (1979). Spray Combustion Models. AIAA Paper, 293, 1-18.

[8] Magnussen, B. F. (1981). On the Structure of Turbulence and a Generalized Eddy Dissipation Concept for Chemical Reaction in Turbulent Flow 1981, Proc. Nineteenth AIAA Meeting, St. Louis.

[9] Pope, S. B. (1997). Computationally efficient implementation of combustion chemistry using in-situ adaptive tabulation. Combustion Theory and Modeling, 1, 41-63.

[10] Welch, M., Igoe, B. M., \& Vilson, D. (2016). Combustion, Fuelsand Emissions for Industrial Gas Turbines. Asia Turbomachinery \& Pump Symposium. Singapore.

[11] Sinkevich, Ye. (2013). Dvukhtoplivnyye GTU kompanii OPRA - garantiya bespereboynoy raboty elektrostantsii [OPRA dual-fuel gas turbines guarantee the uninterrupted operation of a power plant]. Turbiny i dizeli, 1, 8-9 (in Russian).

[12] Brown, J. (2011). Power Uprating on Alstom's Tornado Industrial Gas Turbines. ALSTOM Industrial Gas Turbines, 1, 15.

[13] Kurji, H. J. (2017). Fuel Flexibility with Low Emissions for Gas Turbine Engines. A Thesis for the Degree of Doctor of Philosophy In Mechanical Engineering. Cardif, Great Britan: Cardiff Universit. Retrieved from https://orca.cf.ac. uk/104977/1/2017KurjiHJPhD.pdf.

[14] Ibrahim, I. A., Shabaan, M. M., Shehata, M. A., \& Farag, T. M. (2014). Experimental Investigation of Dual-FuelCombustion Characteristics inside a Gas Turbine CombustorInternational Conference on Machine Learning, Electrical and Mechanical Engineering (ICMLEME'2014). Dubai (UAE). Retrieved from http://iieng.org/images/proceedings_pdf/2853E0114035.pdf.

[15] Hertel, M., Tartsch, D., \& Sattelmayer, S. (2019). Ignition of Diesel Pilot Fuel in Dual-Fuel Engines. Journal of Engineering for Gas Turbines and Power. doi:141.10.1115/1.4043485.

[16] SGT-400 industrial gas turbine. Twin-shaft engine for mechanical drive and power generation. Retrieved from https://www. energy.siemens.com/ru/ru/fossil-power-generation/gas-turbines/sgt-400.htm\#content $=\% \mathrm{D} 0 \% 9 \mathrm{E} \% \mathrm{D} 0 \% \mathrm{BF} \% \mathrm{D} 0 \% \mathrm{~B} 8 \% \mathrm{D} 1 \%$ $81 \% \mathrm{D} 0 \% \mathrm{~B} 0 \% \mathrm{D} 0 \% \mathrm{BD} \% \mathrm{D} 0 \% \mathrm{~B} 8 \% \mathrm{D} 0 \% \mathrm{~B} 5$.

[17] Gas turbine SGT-800 for power generation application (2017). Retrieved from https://www.siemens.com/content/dam/ webassetpool $/ \mathrm{mam} /$ tag-siemens-com/smdb/power-and-gas/Gas\%20Turbines/smallgasturbines/industrial-gas-turbines/sgt800/sgt-800-factsheet-2017.pdf. 


\section{СПИСОК ВИКОРИСТАНОЇ ЛІТЕРАТУРИ}

[1] Директива 2010/75/ЕС Европейского парламента и консилиума от 24 ноября 2010 года о промышленных выбросах (интегрированное предотвращение и контроль загрязнения), Приложение $\mathrm{V}$ «Технические положения, связанные со сжигающими установками». Европейский Союз: Совет Европейского Союза. 2010. Ч. 1, п. 6, 59-61.

[2] Melte P.C., Pratt D.T. Measurement of Atomic Oxygen and Nitrogen Oxides in Jet Stirred Combustion Proc. 15th Symposium (International) on Combustion. The Combustion Institute, USA. 1974. P. 1061-1070.

[3] Lindman O., Andersson M., Persson M., Munktell E. Development of a liquid fuel combustion system for SGT-750 : Proceedings of ASME Turbo Expo 2014 : Turbine Technical Conference and Exposition GT2014, June 16-20, 2014. Germany : Düsseldorf.

[4] Сербин С.И., Вилкул С.В. Исследование влияния параметров распыливания жидкого топлива на температурное поле и экологические характеристики камеры сгорания. Вестник двигателестроения. 2009. № 3. С. 93-97.

[5] Burunsuz K.S., Kuklinovsky V.V., Serbin S.I. Investigations of the emission characteristics of a gas turbine combustor with water steam injection. Refrigeration Engineering and Technology. 2019. № 55 (2). P. 77-83.

[6] Сербін С., Мостіпаненко Г. Числове моделювання процесів горіння в експериментальному відсіку гібридної камери згоряння ГТД потужністю 25 МВт. Вісник Національного технічного університету «Харківський політехнічний інститут» : збірник наукових прачь. Тематичний випуск: "Енергетичні та теплотехнічні прочеси й устаткування». 2006. № 5. 59-67.

[7] Faeth G.M. Spray Combustion Models. AIAA Paper. 1979. № 293. 1-18.

[8] Magnussen B.F. On the Structure of Turbulence and a Generalized Eddy Dissipation Concept for Chemical Reaction in Turbulent Flow 1981. Proc. Nineteenth AIAA Meeting, St. Louis. 1981.

[9] Pope S.B. Computationally efficient implementation of combustion chemistry using in-situ adaptive tabulation. Combustion Theory and Modeling, 1997. № 1. 41-63.

[10] Welch M., Igoe B. M., Vilson, D. Combustion, Fuelsand Emissions for Industrial Gas Turbines. Asia Turbomachinery \& Pump Symposium. Singapore. 2016.

[11] Синкевич Е. Двухтопливные ГТУ компании OPRA - гарантия бесперебойной работы электростанции. Tyрбины $u$ дизели. 2013. № 1. С. 8-9.

[12] Brown J. Power Uprating on Alstom’s Tornado Industrial Gas Turbines. ALSTOM Industrial Gas Turbines. 2011. № 1. P. 15.

[13] Kurji H.J. Fuel Flexibility with Low Emissions for Gas Turbine Engines : A Thesis for the Degree of Doctor of Philosophy In Mechanical Engineering. Cardif, GreatBritan: CardiffUniversit.2017.URL:https://orca.cf.ac.uk/104977/1/2017KurjiHJPhD. pdf.

[14] Ibrahim I.A., Shabaan M.M., Shehata M.A., Farag T.M. Experimental Investigation of Dual-FuelCombustion Characteristics inside a Gas Turbine CombustorInternational Conference on Machine Learning, Electrical and Mechanical Engineering (ICMLEME'2014). Dubai (UAE). 2014. URL: http://iieng.org/images/proceedings_pdf/2853E0114035.pdf.

[15] Hertel M., Tartsch D., Sattelmayer S. Ignition of Diesel Pilot Fuel in Dual-Fuel Engines. Journal of Engineering for Gas Turbines and Power. 2019. Doi:141.10.1115/1.4043485.

[16] SGT-400 industrial gas turbine. Twin-shaft engine for mechanical drive and power generation. URL: https://www.energy. siemens.com/ru/ru/fossil-power-generation/gas-turbines/sgt-400.htm $\#$ content $=\% \mathrm{D} 0 \% 9 \mathrm{E} \% \mathrm{D} 0 \% \mathrm{BF} \% \mathrm{D} 0 \% \mathrm{~B} 8 \% \mathrm{D} 1 \% 81 \% \mathrm{D}$ $0 \% \mathrm{~B} 0 \% \mathrm{D} 0 \% \mathrm{BD} \% \mathrm{D} 0 \% \mathrm{~B} 8 \% \mathrm{D} 0 \% \mathrm{~B} 5$.

[17] Gas turbine SGT-800 for power generation application. 2017. URL: https://www.siemens.com/content/dam/webassetpool/ $\mathrm{mam} / \mathrm{tag}$-siemens-com/smdb/power-and-gas/Gas\%20Turbines/smallgasturbines/industrial-gas-turbines/sgt-800/sgt-800factsheet-2017.pdf. 